\title{
Student Engagement In Civic Learning: A Study For Practice
}

\author{
Patmisari, Sri Setyawati, Achmad Muthali'in, Wibowo Heru Prasetiyo. \\ am244@ums.ac.id \\ Departement od Civic Education \\ Faculty of Teacher Training and Education \\ Universitas Muhammadiyah Surakarta, Surakarta, Indonesia
}

\begin{abstract}
Abstrak
Satu persoalan yang menantang para educator ialah meningkatkan keterlibatan siswa sebagai warga muda ke dalam aktivitas pembelajaran. Dalam konteks pembelajaran kewarganegaraan, keterlibatan siswa di kelas dapat menjadi indikasi pertama dan penting yang menggambarkan kemungkinan mereka di masa depan untuk menjadi warga negara yang aktif dan bertanggung jawab dalam mengelola isu-isu bersama. Lebih dari pada itu, keterlibatan dalam pembelajaran menjadi pretensi terhadap tingkat partisipasi belajar sekaligus optimalisasi student-centered approach. Studi ini dilakukan secara kualitatif pada satu sekolah dengan setting pada pembelajaran civic education. Informan yang dilibatkan terdiri atas guru dan siswa dengan menggunakan teknik wawancara, observasi, dan dokumen. Fokus studi diarahkan kepada pengungkapan bentuk-bentuk keterlibatan siswa dalam pembelajaran civic, kendala guru dalam meningkatkan keterlibatan siswa, dan upaya-upaya untuk mengatasi beberapa kendala yang ada. Hasil penelitian menunjukkan bahwa bentuk keterlibatan siswa ditunjukkan dengan aktif mengerjakan soal yang diberikan guru, tampil di depan kelas, mengungkapkan pendapat, menanggapi pendapat siswa lain. Kendala yang ditemukan adalah tidak semua kemampuan siswa itu sama dalam berpartisipasi. Solusi yang diberikan dalam penelitian ini adalah pengelolaan kelas dengan baik.
\end{abstract}

Kata Kunci: warga muda, keterlibatan siswa, civic education.

\begin{abstract}
The problem that challenges the educators is increasing the engagement of students as young citizens in learning activities. In the context of civics learning, student engagement in the classroom can be the first and important indication that illustrates their future likelihood of becoming active citizens and responsible for managing common issues. More than that, learning engagement becomes a pretension for the level of learning participation as well as optimization of the student-centered approach. This study was conducted qualitatively in a school on civic education learning. The informants involved consisted of teachers and students using interview, observation, and document techniques. The focus of the study is directed at disclosing forms of student involvement in civic learning, teacher constraints in increasing student engagement, and efforts to overcome some of the existing obstacles. The results showed that the form of student engagement was shown by actively working on the questions given by the teacher, appearing in front of the class, expressing opinions, responding to the opinions of other students. The obstacle found was that not all students' abilities were the same in participating. The solution given in this research is good classroom management.
\end{abstract}

Keyword: youth citizen, student engagement, civic education

Peer reviewed under responsibility of Universitas Nusantara PGRI Kediri.

(C) 2021 Patmisari, Sri Setyawati, Achmad Muthali'in, Wibowo Heru Prasetiyo

This is an open access article under the CC BY-SA license

( https://creativecommons.org/licenses/by-sa/4.0/ ) 
Jurnal PINUS: Jurnal Penelitian Inovasi Pembelajaran, 6 (2), 2021, Patmisari, Sri Setyawati, Achmad Muthali'in, Wibowo Heru Prasetiyo

\section{PENDAHULUAN}

Pendidikan nasional berfungsi
mengembangkan kemampuan dan membentuk watak serta peradaban bangsa yang bermartabat dalam rangka mencerdaskan kehidupan bangsa, bertujuan untuk berkembangnya potensi peserta didik agar menjadi manusia yang beriman dan bertakwa kepada Tuhan Yang Maha Esa, berakhlak mulia, sehat, berilmu, cakap, kreatif, mandiri, dan menjadi warga negara yang demokratis serta bertanggung jawab (UU No. 20 Tahun 2003 Pasal 3). Guna merealisasi fungsi tersebut dirumuskan kurikulum di berbagai jenjang pendidikan. Dalam kurikulum dimaksud dicantumkan berbagai mata pelajaran yang harus ditempuh peserta didik, salah satunya mata pelajaran Pendidikan Pancasila dan Kewarganegaraan (PPKn).

PPKn merupakan salah satu mata pelajaran untuk mengembangkan potensi peserta didik menjadi warga negara yang demokratis. PPKn merupakan mata pelajaran wajib untuk jenjang SD/MI, SMP/MTs, SMA/SMK/MA. Mata pelajaran ini juga dirancang untuk menghasilkan peserta didik yang memiliki keimanan dan akhlak mulia sebagaimana diarahkan oleh falsafah Pancasila, sehingga nantinya dapat berperan sebagai warga negara bertanggung jawab. Secara lebih singkat PPKn merupakan wahana untuk membentuk peserta didik menjadi manusia yang memiliki rasa kebangsaan dan cinta tanah air (Winataputra, 2012:19).

PPKn di tingkat persekolahan bertujuan untuk mempersiapkan para peserta didik sebagai warga negara yang cerdas dan baik (to be smart dan good citizen) berdasarkan nilai-nilai Pancasila. Di dalamnya mencakup warga negara yang menguasai pengetahuan (knowledge), sikap dan nilai (attitudes and values), keterampilan (skills) yang dapat dimanfaatkan untuk menumbuhkan rasa kebangsaan dan cinta tanah air sebagai wujud implementasi dan aktualisasi nilai-nilai Pancasila. Berdasarkan tujuan tersebut, PPKn diharapkan mampu membentuk warga negara yang cerdas dan baik, warga negara yang peka, tanggap, kritis, dan kreatif dalam konteks kehidupan bermasyarakat, berbangsa, dan bernegara. Hal tersebut dilakukan secara tertib, damai, dan kreatif, sebagai cerminan dan pengejawantahan nilai, norma dan moral Pancasila. Peserta didik dikondisikan selalu bersikap kritis dan berperilaku kreatif sebagai anggota keluarga, warga sekolah, anggota masyarakat, warga negara, dan umat manusia di lingkungannya secara cerdas dan baik. Proses pembelajaran diorganisasikan dalam bentuk belajar sambil berbuat (learning by doing), belajar memecahkan masalah sosial (social problem solving learning), belajar melalui perlibatan sosial (socioparticipatory learning), dan belajar melalui interaksi sosial kultural sesuai dengan konteks kehidupan masyarakat (Kemendikbud RI, 2014:2).

PPKn secara filosofis dan substantif-pedagogis atau adragogis, merupakan pendidikan untuk memfasilitasi perkembangan pribadi peserta didik agar menjadi warga negara Indonesia yang religius, berkeadaban, 


\section{Jurnal PINUS: Jurnal Penelitian Inovasi Pembelajaran, 6 (2), 2021, Patmisari, Sri Setyawati, Achmad Muthali'in, Wibowo Heru Prasetiyo}

berjiwa persatuan Indonesia, demokratis dan bertanggung jawab, dan berkeadilan, serta mampu hidup secara harmonis dalam konteks multikulturalismebhinneka tunggal ika. Kondisi Indonesia yang multikultural, menuntut berkembangnya "civic virtue" atau kebajikan atau akhlak kewarganegaraan. Kebajikan itu sepenuhnya harus terpancar dari nilai-nilai Pancasila yang secara subtantif mencakup keterlibatan aktif warga negara, hubungan kesejajaran saling percaya dan toleran, kehidupan yang kooperatif, solidaritas, dan semangat kemasyarakatan multikultural (Winataputra, 2012:141-142).

Pembelajaran PPKn merupakan cara dalam pengembangan kemampuan berpartisipasi belajar peserta didik sebagai warga negara yang baik. Thompson (2015) dalam Journal of Education Citizenship and Social Justice mengenai Teachers "Views on Students" Experiences of Community Involvement and Citizenship Education terjemahan dalam bahasa Indonesia mengemukakan bahwa "Akhlak kewarganegaraan ditanamkan oleh guru dalam mempersiapkan peserta didik mereka untuk dapat berpartisipasi aktif”. Akhlak kewarganegaraan lainnya adalah kemamuan, kemampuan, dan keterampilan peserta didik sebagai warga negara dalam memecahkan pemecahan masalah sosial-kultur kewarganegaraan di lingkungannya (Kemendikbud RI, 2014:2). Fives (2015) dalam Journal of Non-Coercive Promotion of Valuesi in Civic Education for Democracy terjemahan dalam bahasa Indonesia mengemukakan bahwa "pendidikan kewarganegaraan dilakukan oleh guru untuk membekali peserta didik mempunyai sikap yang demokratis dan sikap yang baik. Hal tersebut antara lain yaitu peserta didik diajarkan mengenai sikap kejujuran, adil dan saling menghormati. Dalam sikap tersebut akan membentuk warga negara di masa depan pada peserta didik".

Indikator tolok ukur partisipasi belajar dalam pengembangan kemampuan siswa berpartisipasi sebagai warga negara dalam pembelajaran PPKn meliputi aktif mengerjakan soal yang diberikan guru yaitu peserta didik berpartisipasi aktif dalam mengerjakan soal di kelas baik secara individu atau kelompok dalam proses pembelajaran berlangsung. Menjawab pertanyaan atau mengerjakan soal di depan kelas yaitu peserta didik aktif berpartisipasi menjawab soal yang diberikan oleh guru baik tugas tertulis maupun pengerjakan soal di depan kelas. Memberi tanggapan dan mengajukan ide yaitu respon peserta didik dalam pembelajaran di kelas serta upaya dalam memberikan ide terkait materi pembelajaran berlangsung. Berani memberikan tanggapan terhadap siswa lain yaitu peserta didik mempunyai keberanian dalam merespon balik atas tanggapan temannya dalam adu respon kelompok di kelas. Membuat kesimpulan dari materi baik secara mandiri atau kelompok yaitu peserta didik membuat inti dari proses pembelajaran di kelas baik secara individu maupun kelompok terkait materi yang telah diajarkan oleh guru.

Mata pelajaran PPKn sampai saat ini masih dianggap sebagai mata pelajaran yang membosankan dan kurang diminati oleh sebagian peserta didik. Proses pembelajaran ini cenderung 


\section{Jurnal PINUS: Jurnal Penelitian Inovasi Pembelajaran, 6 (2), 2021, Patmisari, Sri Setyawati, Achmad Muthali'in, Wibowo Heru Prasetiyo}

dilakukan guru dengan menggunakan metode ceramah yang menjadi pilihan utama strategi pembelajaran dan memberikan tugas kepada peserta didik. Kurangnya media yang digunakan dalam proses pembelajaran tersebut, membuat peserta didik merasa bosan dan pada akhirnya proses belajar-mengajar menjadi tidak menarik dan terkesan membosankan (Rachmawati, 2016).

Berdasarkan hasil penelitian beberapa tahun, terdapat temuan bawa siswa dan guru cenderung minimalis dalam berdiskusi. Guru sering menganggap pengkajian materi sebagai diskusi, ketika guru memulai pertanyaan, siswa menanggapi dan guru mengevaluasi jawaban benar, salah atau membutuhkan modifikasi atau elaborasi. Siswa tampaknya menganggap setiap kesempatan untuk berbicara sebagai diskusi, termasuk memberi jawaban dalam bacaan. Siswa merasa mereka 'berdiskusi' masalah dalam iklim terbuka dan mendukung, di mana siswa merasa nyaman mengekspresikan pandangan mereka bahkan ketika mereka berbeda dari pandangan guru dan siswa lain, kemudian siswa melaporkan tingkat kepentingan politik, kepercayaan dan keyakinan bahwa mereka dan orangorang seperti mereka dapat membuat perbedaan. Siswa yang memahami sebuah iklim diskusi terbuka lebih luas dan cenderung berharap untuk memilih sebagai orang dewasa (Hahn, 2016).

Doppen (2015) dalam Journal of Citizenship, Social and Economics mengenai Young Adolescents" Knowledge and Notions of Citizenship terjemahan dalam bahasa Indonesia mengemukakan bahwa "Salah satu tujuan terpenting pendidikan formal di AS, atau negara lain yaitu untuk mengembangkan warga yang aktif dan berpengetahuan". Selain Amerika Serikat, Selandia Baru dalam berbagai jenjang Pendidikan Kewarganegaraan juga mengembangkan kemampuan peserta didik untuk aktif terlibat di masyarakat secara demokratis.

Mutch (2011) dalam Journal of Citizenship Education in New Zealand: we know , what works " but to what extent is it working? terjemahan dalam bahasa Indonesia mengemukakan bahwa "Pendidikan kewarganegaraan diberbagai negara seringkali didasarkan pada aspirasi dengan memberikan wawasan masyarakat dan sikap menjadi warga negara yang demokratis".

Hasil penelitian di atas terdapat persamaan dengan penelitian ini, yaitu keduanya sama-sama meneliti mengenai keberhasilan dalam mengembangkan kemampuan siswa berpartisipasi sebagai warga negara dalam pembelajaran PPKn, perbedaanya terletak pada subjek dimana penelitian ini dilaksanakan di sekolah Indonesia yaitu SMP Muhammadiyah 4 Surakarta.

Karakteristik di atas dalam pembelajaran PPKn diharapkan mampu mempersiapkan anak didiknya ketika dihadapkan pada sebuah realitas kehidupan saat ini yang mampu berpartisipasi sebagai warga negara dalam masyarakat dengan baik. Untuk membentuk warga negara yang tahu dan mampu menempatkan dirinya dalam suatu negara, maka masyarakat harus dibimbing agar nantinya mampu menjadi warga negara yang diharapkan. Maka pembelajaran PPKn dilakukan untuk mengembangkan tiga komponen pokok 


\section{Jurnal PINUS: Jurnal Penelitian Inovasi Pembelajaran, 6 (2), 2021, Patmisari, Sri Setyawati, Achmad Muthali'in, Wibowo Heru Prasetiyo}

sebagai potensi warga negara agar memiliki civic knowledge (pengetahuan warga negara), civic values/disposition (nilai/karakter warga negara), dan civic skill (keterampilan warga negara). Berkaitan dengan hal tersebut, maka secara esensial peran guru PPKn adalah membentuk peserta didik untuk menamkan kemampuan berpartisipasi sebagai warga negara yang sesuai dengan nilai serta norma kehidupan berbangsa dan bernegara.

Berdasarkan latar belakang masalah di atas, permasalahan penelitian ini adalah: 1) bagaimana analisis kemampuan berpartisipasi sebagai warga negara dalam pembelajaran PPKn pada siswa SMP Muhammadiyah 4 Surakarta?; 2) bagaimana kendala analisis kemampuan berpartisipasi sebagai warga negara dalam pembelajaran PPKn pada siswa SMP Muhammadiyah 4 Surakarta?; 3) bagaimana solusi untuk mengatasi kendala analisis kemampuan berpartisipasi sebagai warga negara dalam pembelajaran PPKn pada siswa SMP Muhammadiyah 4 Surakarta?.

Berdasarkan rumusan masalah di atas, tujuan penelitian ini yaitu 1) untuk mendeskripsikan analisis kemampuan berpartisipasi sebagai warga negara dalam pembelajaran PPKn pada siswa SMP Muhammadiyah 4 Surakarta; 2) untuk mendeskripsikan kendala dalam analisis kemampuan berpartisipasi sebagai warga negara dalam pembelajaran PPKn pada siswa SMP Muhammadiyah 4 Surakarta; 3) untuk mendeskripsikan solusi untuk mengatasi analisis kemampuan berpartisipasi sebagai warga negara dalam pembelajaran PPKn pada siswa SMP Muhammadiyah 4 Surakarta.

\section{METODE}

Penelitian ini dilakukan di SMP Muhammadiyah 4 Surakarta. Tahaptahap pelaksanaan dalam penelitian ini dimulai dari persiapan sampai dengan penulisan laporan penelitian. Secara keseluruhan semua kegiatan dilakukan selama kurang lebih 4 bulan, yaitu sejak April sampai Juli 2019. Jenis penelitian ini menggunakan metode deskriptif kualitatif interaktif dengan studi kasus, karena analisis data yang digunakan berupa kata-kata tertulis atau lisan dan mempertimbangkan asusmsi atau pendapat narasumber atau informan. Kasus dalam penelitian ini mengenai analisis kemampuan berpartisipasi sebagai warga negara dalam pembelajaran PPKn pada siswa SMP Muhammadiyah 4 Surakarta.

Penelitian ini menggunakan teknik pengumpulan data meliputi observasi, wawancara, dan dokumentasi. Teknik analisisnya menerapkan model interaktif. Analisis data merupakan proses mencari dan menyusun data secara sistematis yang diperoleh melalui wawancara, catatan lapangan dan dokumentasi dengan cara mengelompokan data ke dalam kategori, menjabarkan kedalam unit-unit, melakukan sintesa, menyusun kedalam pola, memilih mana yang penting dan yang akan dipelajari, dan membuat kesimpulan sehingga mudah dipahami oleh diri sendiri maupun orang lain (Sugiyono, 2013). 
Jurnal PINUS: Jurnal Penelitian Inovasi Pembelajaran, 6 (2), 2021, Patmisari, Sri Setyawati, Achmad Muthali'in, Wibowo Heru Prasetiyo

HASIL

Pengembangan kemampuan siswa berpartisipasi sebagai warga negara dalam pembelajaran PPKn dapat diamati melalui aktif mengerjakan soal yang diberikan guru dengan pekerjaan individu atau kelompok, menjawab pertanyaan atau mengerjakan soal di depan kelas dengan sikap peserta didik dalam berpartisipasi menjawab soal, memberi tanggapan dan mengajukan ide dengan melihat respon peserta didik dalam memberi umpan balik, berani memberikan tanggapan terhadap jawaban siswa lain dengan melihat rasa berani peserta didik dalam merespon jawaban teman, serta membuat kesimpulan dari materi baik secara mandiri atau kelompok dengan membuat inti proses prmbelajaran terkait materi yang telah diajarkan oleh guru.

\section{Aktif Mengerjakan Soal yang Diberikan Guru.}

Analisis

kemampuan

berpartisipasi terkait aktif mengerjakan soal yang diberikan guru dimaksudkan adanya bentuk keikutsertaan dengan antusias siswa dalam proses pengerjakan soal yang diberikan guru baik individu maupun kelompok di kelas. Terdapat keaktifan peseta didik aktif dalam mengerjakan soal yang diberikan oleh guru dalam pembelajaran berlangsung di kelas, yaitu terbukti dengan siswa mengikuti kegiatan belajar dengan baik. Analisis kemampuan berpartisipasi sebagai warga negara dalam pembelajaran PPKn tersebut ditanamkan melalui belajar mengerjakan soal di dalam kelas, serta keikutsertaan siswa dalam mengikuti kegiatan pembelajaran.
Setiap pelaksanaan pembelajaran partisipasi belajar masih terdapat hambatan-hambatan pada saat proses pembelajaran. Kendala tersebut mengenai siswa kurang berpartisipasi aktif mengerjakan soal yang diberikan guru. Keaktifan siswa dalam mengerjakan soal tidak selalu berjalan dengan baik. Banyak siswa yang tidak mengerjakan karena tidak mengerti jawaban mengenai pertanyaan tersebut. Hal tersebut disebabkan siswa tidak memperhatikan guru saat menjelaskan, tidak mengerti materi yang disampaikan dan mejadikan siswa mengkosongi jawaban.

Solusi agar siswa aktif mengerjakan soal yang diberikan guru dalam proses pembelajaran di kelas khususnya mata pelajaran PPKn, yaitu guru memberikan pengarahan kepada siswa agar aktif mengerjakan soal dan berkeliling untuk menegur siswa yang malas mengerjakan soal. Hal ini sekaligus merupakan penguat agar siswa bertanggung jawab aktif mengerjakan soal yang diberikan guru.

\section{Menjawab Pertanyaan atau} Mengerjakan Soal di Depan Kelas.

Partisipasi belajar terkait menjawab pertanyaan dan mengerjakan soal di depan kelas dimaksudkan siswa aktif berpartisipasi menjawab soal yang diberikan oleh guru baik tugas tertulis maupun pengerjakan soal di depan kelas. Menjawab pertanyaan atau mengerjakan soal di depan kelas dalam proses pembelajaran khususnya mata pelajaran PPKn, yaitu berjalan dengan baik dan lancar, serta siswa mengerjakan pertanyaan dengan baik sesuai perintah 
Jurnal PINUS: Jurnal Penelitian Inovasi Pembelajaran, 6 (2), 2021, Patmisari, Sri Setyawati, Achmad Muthali'in, Wibowo Heru Prasetiyo

guru. Sekaligus merupakan penanaman partisipasi siswa sebagai warga negara.

Akan tetapi tidak semua siswa mampu mengikuti petunjuk guru untuk mengerjakan soal di depan kelas. Terdapat kendala kurangnya partisipasi dalam menjawab pertanyaan atau mengerjakan soal yang diberikan guru tersebut tercantum pada nilai yang diberikan guru, umumnya nilai tidak maksimal. Solusi dalam kendala ini yaitu guru memotivasi siswa dan menambah nilai lebih kepada siswa, sangat mempengaruhi siswa untuk mengerjakan soal di depan kelas.

\section{Memberi Tanggapan dan Mengajukan} Ide.

Analisis kemampuan siswa berpartisipasi terkait memberi tanggapan dan mengajukan ide dimaksudkan dengan respon siswa dalam pembelajaran di kelas serta upaya dalam memberikan ide terkait materi pembelajaran berlangsung. Partisipasi belajar dalam memberi tanggapan dan mengajukan ide pada mata pelajaran PPKn pada siswa SMP Muhammadiyah 4 Surakarta berjalan dengan baik. Sekaligus merupakan penanaman partisipasi siswa sebagai warga negara.

Akan tetapi terdapat kendala dalam pembelajaran ini yaitu siswa kurang aktif dalam memberi tanggapan ketika pembelajaran berlangsung, dilihat dari siswa tidur ketika jam pelajaran dan kurang dalam memperhatikan yang biasanya sering dilakukan pada waktu siang hari. Solusi yang diberikan adalah penyampaian materi menggunakan metode pembelajaran agar siswa tertarik untuk memperhatikan materi yang disampaikan oleh guru dan memancing siswa agar memberi tanggapan dan mengeluarkan ide.

\section{Berani Memberikan Tanggapan terhadap Jawaban Siswa Lain.}

Kemampuan partisipasi belajar terkait berani memberikan tanggapan terhadap jawaban siswa lain dimaksudkan bahwa setiap siswa mempunyai keberanian dalam merespon balik atas tanggapan temannya dalam adu respon kelompok di kelas. Siswa aktif dalam bertanya serta memberi tanggapan terhadap siswa lain, saling menanggapi materi yang masih belum dipahami, bahkan hasil tersebut ditulis siswa di buku tulis oleh masing-masing individu. Partisipasi belajar dilihat dari keberanian peserta didik dalam menanggapi jawaban siwa lain pada mata pelajaran PPKn di SMP Muhammadiyah 4 Surakarta berjalan dengan baik. Dilihat ketika peserta didik berani merespon balik teman ketika proses pembelajaran di kelas. Sekaligus merupakan penanaman dan pengembangan partisipasi siswa sebagai warga negara.

Akan tetapi kendala dari pelaksanaan pembelajaran ini yaitu keberanian siswa dalam menanggapi tanggapan terhadap jawaban siswa lain sangat kurang ketika pembelajaran berlangsung. Hal tersebut menyebabkan siswa kurang dalam kemampuan partisipasi sebagai warga negara. Solusi agar siswa berpartisipasi aktif berani memberikan tanggapan terhadap jawaban siswa lain yaitu guru mebantu siswa untuk menyampaikan pendapatnya. Guru juga memotivasi serta memberikan gambaran awal agar siswa memiliki rasa percaya diri serta berani dalam 
Jurnal PINUS: Jurnal Penelitian Inovasi Pembelajaran, 6 (2), 2021, Patmisari, Sri Setyawati, Achmad Muthali’in, Wibowo Heru Prasetiyo

mengungkapkan tanggapan dengan temannya.

\section{Membuat Kesimpulan dari Materi Baik Secara Mandiri atau Kelompok.}

Partisipasi belajar siswa terkait membuat kesimpulan dari materi baik secara mandiri atau kelompok dimaksudkan siswa membuat inti dari proses pembelajaran di kelas baik secara individu maupun kelompok terkait materi yang telah diajarkan oleh guru. Ketika akhir pembelajaran, guru dan siswa bersama-sama menyimpulkan materi pembelajaran yang sudah diajarkan. Siswa lalu menulis kesimpulan tersebut yang berfungsi untuk mempermudah memahami inti dari penjelasan guru. Partisipasi belajar dalam membuat kesimpulan dari materi, baik secara mandiri atau kelompok mata pelajaran PPKn pada siswa SMP Muhammadiyah 4 Surakarta berjalan dengan baik ketika pembelajaran berlangsung di kelas. Sekaligus merupakan penanaman partisipasi siswa sebagai warga negara.

Kendala dalam partisipasi belajar dalam membuat kesimpulan baik secara individu maupun kelompok yaitu waktu pembelajaran sudah mau habis membuat pikiran siswa tidak fokus kembali dan kurang menarik siswa ketika waktu pembelajaran terlalu lama. Solusi dalam kendala ini yaitu guru mendampingi siswa dalam membuat kesimpulan di kelas ketika akhir pembelajaran berlangsung.

\section{PEMBAHASAN}

Permasalahan kewarganegaraan membutuhkan perhatian yang lebih besar dalam kebijakan pendidikan, baik di sekolah maupun pembuat kebijakan
(Campbell \& Niemi, 2016). Pendidikan Pacasila dan Kewarganegaraan, melalui mata pelajaran tersebut warga Negara Kesatuan Republik Indonesia diharapkan mampu memahami, menganalisis, dan menjawab masalah-masalah yang dihadapi oleh masyarakat, bangsa dan negara secara berkesinambungan dan konsisten dengan cita-cita dan tujuan nasional seperti yang digariskan dalam pembukaan UUD 1945. Keberhasilan dalam Pendidikan Kewarganegaraan akan menumbuhkan sikap mental yang cerdas dan penuh tanggung jawab.

Pendidikan kewarganegaraan sangat penting untuk menumbuhkan keterlibatan kewarganegaraan. Tingkat keterlibatan kewargangearaan meningkat seiring dengan tingkat pendidikan formalnya (Mirra \& Garcia, 2017). Partisipasi siswa di sekolah dan di masyarakat memiliki dampak positif pada kesediaan mereka untuk terlibat dalam tindakan kewarganegaraan untuk mempromosikan isu-isu penting demokrasi di masa datang (Reichert \& Print, 2018).

Oleh karena itu diperlukan keterlibatan terhadap kewarganegaraan yang dimulai dari keterlilbatan siswa dalam kelas (student engagement). Selain di lingkungan sekolah, teman sebaya juga mampu mempengaruhi student engagement. Teman sebaya membawa pengaruh penting dalam keterlibatan kewarganegaraan. Kelompok sebaya yang mempertahankan norma-norma untuk keterlibatan kewarganegaraan memiliki potensi untuk memengaruhi keyakinan pemuda. Selain itu, usia juga merupakan faktor dalam mendorong partisipasi kewargangearaan karena 
Jurnal PINUS: Jurnal Penelitian Inovasi Pembelajaran, 6 (2), 2021, Patmisari, Sri Setyawati, Achmad Muthali'in, Wibowo Heru Prasetiyo

bertambahnya usia berarti memiliki akses peluang yang lebih luas dalam aktivitas sosial teman budaya (Rossi et al., 2016).

$\begin{array}{ccc}\text { Kewarganegaraan } & \text { berdasarkan } \\ \text { kewajiban dan } & \text { keterlibatan }\end{array}$

kewarganegaraan hanya sebagian dari cerita. Warga negara yang menganut ini memiliki potensi cukup besar yang berdampak pada hasil politik nyata seperti aksi lingkungan, keikutsertaan dalam pemilihan. Analisis level individu menunjukkan bahwa status tinggi responden adalah hal pertama yang mendukung keterlibatan warga negara, hal ini tidak berarti bahwa norma-norma juga lazim di negara berpenghasilan tinggi. Warga negara di negara demokrasi maju mungkin lebih mudah untuk stabilitas demokrasi. Sebaliknya di negara demokrasi yang lebih baru, melibatkan diri sendiri merupakan sesuatu yang lebih dipikirkan oleh warga negara muda (Hooghe et al., 2016).

Pembelajaran PPKn akan efektif jika didalamnya memberikan pelatihan keterampilan bagi siswa sebagai warga negara, salah satunya adalah partisipasi aktif. Partisipasi aktif siswa akan muncul melalui interaksi pembelajaran yang partisipatif. Keterampilan partisipasi aktif dimaksudkan untuk memberdayakan peserta didik dalam merespon dan memecahkan masalah dalam kehidupan bermasyarakat (Azra, 2005: 12).

\section{Kegiatan}

pembelajaran

diharapkan dapat meningkatkan kemampuan siswa dalam kompetensi sikap, pengetahuan, dan keterampilan yang diperlukan dirinya untuk hidup bermasyarakat, berbangsa, dan berkontribusi pada kesejahteraan hidup manusia. Mata pelajaran PPKn selalu menyangkut kompetensi pengetahuan, watak dan keterampilan.

Kompetensi kehadiran

Pendidikan Pancasila dan

Kewarganegaraan adalah dimana masyarakat dan pendidikan suatu negara berupaya untuk menjamin kelangsungan hidup serta kehidupan generasi berikutnya. Generasi penerus tersebut diharapkan akan mampu mengantisipasi hari depan bangsa yang senantiasa berubah dan selalu terkait dengan konteks dinamika budaya, bangsa, negara, dan hubungan internasional. Kompetensi Pendidikan Pancasila dan Kewarganegaraan adalah didapatkannya tindakan cerdas yang penuh tanggung jawab dari seorang warga negara dalam berhubungan dengan negara dan memecahkan berbagai masalah hidup masyarakat, berbangsa, dan bernegara dengan menerapkan konsepsi falsafah negara, wawasan nusantara, dan ketahanan nasional (Darmadi, 2013).

Berdasarkan uraian teori di atas dapat disimpukan bahwa kompetensi kemampuan berpartisipasi di PPKn sejalan dengan pengembangan dan penerapan kurikulum di sekolah menengah, maka siswa juga harus memiliki kompetensi yang mencakup tiga ranah yaitu kognitif, afektif dan psikomotorik. Pembelajaran PPKn akan efektif jika di dalamnya memberikan pelatihan keterampilan bagi siswa sebagai warga negara, salah satunya adalah berpartisipasi aktif. Adapun indikator partisipasi belajar antara lain:

1. Aktif mengerjakan soal yang diberikan guru. 
Jurnal PINUS: Jurnal Penelitian Inovasi Pembelajaran, 6 (2), 2021, Patmisari, Sri Setyawati, Achmad Muthali'in, Wibowo Heru Prasetiyo

2. Menjawab pertanyaan atau mengerjakan soal di depan kelas.

3. Memberi tanggapan terhadap jawaban siswa lain.

4. Membuat kesimpulan dari materi baik secara mandiri atau kelompok.

Hasil penelitian menunjukkan bahwa akhlak kewarganegaraan di tanamkan oleh guru dalam mempersiapkan peserta didik mereka untuk dapat berpartisipasi aktif. Partisipasi di maksud yaitu mengenai keterlibatan sikap peserta didik dalam kegiatan masyarakat. Hal tersebut berhasil dilakukan dalam menerapkan strategi untuk membekali siswa dengan pemahaman konseptual tentang peran peserta didik sebagai warga negara untuk saling berinteraksi secara langsung dengan baik. Pembentukan akhlak kewarganegaraan tersebut diteliti oleh berbagai negara, salah satunya Amerika Serikat. Salah satu tujuan terpenting pendidikan formal di AS atau negara lain yaitu untuk mengembangkan warga yang aktif dan berpengetahuan. Peserta didik perlu dibekali sikap berpartisipasi sebagai warga negara dan harus memiliki pengetahuan kritis tentang masalah sosial, politik dan kewarganegaraan. Hal ini sejalan dengan penelitian Fives (2015), mengenai penguatan akhlak kewarganegaraan dalam berbagai nilainilai kepada peserta didik, termasuk demokrasi. Hasil penelitian tersebut menunjukkan bahwa pendidikan kewarganegaraan dilakukan oleh guru untuk membekali peserta didik mempunyai sikap yang demokratis dan sikap yang baik.

Keterlibatan siswa telah menjadi focus upaya untuk memahami dan meningkatkan pembelajaran siswa.
Keterlibatan siswa membutuhkan banyak hal membentuk pada berbagai tingkatan (kognitif, afektif, dan perilaku) di dalam dan luar kelas (Groccia, 2018).

Keterlibatan kewarganegaraan yang dimulai dari lingkungan kelas dilakukan dengan siswa aktif berpartisipasi di dalam kelas seperti aktif tampil di depan kelas, berani mengemukakan pendapat dan berani menanggapi tanggapan seperti yang telah dijelaskan dalam hasil penelitian. Kurikulum dan dokumen kebijakan sering mendukung siswa menjadi warga negara yang aktif sebagai tujuan utama dari sekolah (Baroutsis et al., 2016). Komponen penting dari pembelajaran siswa untuk menjadi warga negara aktif dan praktik kewarganegaraan adalah 'suara siswa' atau kemampuan pedagogik siswa untuk bersuara, melakukan kegiatan yang demokratis. Hendaknya suara siswa diintegrasikan ke dalam pembelajaran dan kurikulum (Baroutsis et al., 2016). Siswa diberikan kesempatan untuk bersuara, dan guru berperan penting untuk mendengarkan. Mendengarkan, berdialog, bernegosiasi aktif, siswa akan merasa terlibat dalam proses pembelajaran. Bernegosiasi maksudnya menyediakan pilihan kepada siswa tentang diskusi apa, fasilitas apa, dll. Ketika siswa didengarkan maka mereka akan merasa aman, dihargai dan yang penting merasa didengarkan.

Kendala dalam pengembangan kemampuan siswa berpartisipasi sebagai warga negara dalam pembelajaran PPKn di SMP Muhammadiyah 4 Surakarta, yaitu kurang paham materi karena siswa tidak memperhatikan kurangnya rasa percaya diri atas jawaban yang sudah 
Jurnal PINUS: Jurnal Penelitian Inovasi Pembelajaran, 6 (2), 2021, Patmisari, Sri Setyawati, Achmad Muthali'in, Wibowo Heru Prasetiyo

dikerjakannya sendiri, siswa tertidur di kelas dan kurang fokus belajar sehingga tidak paham materi dan tidak memberi tanggapan, kurangnya rasa percaya diri dalam menyampaikan pendapat dan waktu habis untuk menyampaikan materi sehingga tidak cukup untuk memberikan kesimpulan. Kendala di atas adalah hambatan dalam proses pembelajaran, namun hal tersebut terdapat solusi untuk mengatasi agar siswa mengembangkan kemampuan berpartisipasi sebagai warga negara dalam pembelajaran PPKn dengan baik.

Solusi yang diberikan untuk mengatasi kendala yang terjadi pada analisis kemampuan berpartisipasi sebagai warga negara dalam pembelajaran PPKn pada siswa SMP Muhammadiyah 4 Surakarta, yaitu dengan cara pengelolaan kelas yang baik oleh guru, memotivasi siswa untuk menjawab pertanyaan atau mengerjakan soal di depan kelas, menggunakan metode pembelajaran yang menarik siswa, guru memberikan ide awal dan guru tidak memperbolehkan siswa keluar terlebih dahulu sebelum pemnyampaian kesimpulan. Solusi di atas merupakan cara untuk mengatasi kendala dalam analisis kemampuan berpartisipasi sebagai warga negara dalam pembelajaran PPKn.

Keterlibatan siswa tidak hanya terkait dengan karakteristik individu tetapi juga untuk variabel kelas. Sebagian besar perbedaan antar kelas dalam perilaku siswa, kognitif dan keterlibatan emosi terkait dengan penyediaan dukungan otonomi dan struktur guru di kelas. Keterlibatan siswa di dalam kelas berbeda-beda karena masing-masing guru memainkan peran untuk muridmuridnya dan kuncinya adala bagaimana menarik perhatian tentang manfaat menyediakan bagi siswa dan dengan dukungan otonomi yang saling melengkapi. Proses motivasi mediasi model, merasa dukungan otonomi secara terus menerus dapat meningkatkan keterlibatan siswa karena pendidikan berubah kedalam kebutuhan kepuasan (Jang et al., 2016). Dukungan otonomi mungkin baik untuk keterlibatan, tetapi struktur memiliki peran lebih penting. Lingkungan belajar benar-benar dibentuk oleh guru di tingkat kelas penting untuk keterlibatan siswa. Di luar pengaruh karakteristik siswa dan komposisi kelas. Membekali siswa dengan struktur penting untuk menopang keterikatan mereka,. Dukungan otonomi dapat bermanfaat, khususnya tentang keterlibatan emosional selama pelajaran (Hospel \& Galand, 2016).

Melalui keterlibatan siswa di dalam studi mereka, siswa belajar tidak hanya memperoleh ketrampilan dan pengetahuan tetapi juga mengalami kesuksesan akademis dan perkembangan diri (Kahu \& Nelson, 2018). Berdasarkan penelitian yang dilakukan Kahu (2013) menegaskan bahwa keterlibatan ssiwa dipengarui interaksi antara faktor siswa dengan faktor kelembagaan dengan menerapkan budaya, interaksi yang terjadi antar pendidikan. Sebuah interaksi dapat mempengarui keterlibatan siswa secara tidak langsung.

Iklim ruang kelas yang terbuka untuk diskusi merupakan kunci dari keterlibatan kewarganegaraan. Pengunaan pengajaran konseptual dan keterlibatan siswa, seperti iklim kelas 
Jurnal PINUS: Jurnal Penelitian Inovasi Pembelajaran, 6 (2), 2021, Patmisari, Sri Setyawati, Achmad Muthali’in, Wibowo Heru Prasetiyo

yang terbuka merupakan predictor dalam pencapaian kognitif kewarganegaraan (Knowles et al., 2018).

Guru harus mendukung otonomi siswa, karena dukungan dari guru sangat berpengaruh terhadap keterlibatan siswa, konsentrasi siswa, manajemen waktu belajar yang lebih baik, kebijakan diri sendiri dan kinerja yang lebih tinggi. Guru memberikan bimbingan, arahan dan harapan dengan cara mendukung otonomi mereka, meningkatkan keterlibatan siswa dalam pembelajaran yang berpusat pada siswa dan memperoleh hasil pembelajaran yang diinginkan. Kerangka pembelajaran untuk meningkatkan keterlibatan siswa dalam pembelajaran berpusat pada siswa yaitu dengan memiliki, pelajari dan membagikannya (Lee \& Hannafin, 2016). Yang pertama siswa perlu memahami bahwa proses pembelajaran juga menjadi miliknya dan praktik menjadi lebih otonom. Setelah merasa memiliki, siswa perlu mempelajari. Upaya yang dilakukan guru yaitu dengan memandu apa yang harus dilakukan, mempertimbangkan manajemen pembelajaran, dan memberikan alternatif untuk dipertimbangkan. Tahap terakir yaitu dengan membagikan, keterlibatan siswa dilanjutkan dengan menyajikan berbagai produk dengan penonton.

Membangun keterlibatan siswa memerlukan peningkatan proses dan struktur yang membantu pembelajaran seperti pembelejaran virtual atau tatap muka dengan cara yang responsive terhadap kebutuhan siswa yang semakin beragam. Keterlibatan siswa juga bisa dilakukan dengan membentuk kelompok, yang di dalamnya mereka akan bersama- sama membicarakan isi dari pembelajaran. Menjadi anggota dalam sebuah kelompok, berkolaborasi tatap muka dan online, komunikasi dan diskusi meningkatkan keterlibatan siswa, kepercayaan diri dan rasa memiliki (Masika \& Jones, 2016).

Membentuk dan menciptakan kelas yang mendukung lingkungan kelas menjadi cara utama yang dapat dilakukan guru dalam keterlibatan pembelajaran (Shernoff et al., 2016).Untuk pendidikan yang lebih tinggi relevan dengan minat siswa dan tujuan masa depan yaitu sangat penting untuk kesuksesan. Analisis menekankan bawa peran penting baik individu maupun situasi menarik dalam memfasilitasi keterlibatan siswa, yang kemudian mengarah kepada hasil positif siswa. Pemahaman dari fungsi minat dapat dilihat dari tiga cara, yaitu pertama ketika membentuk lingkungan kelas dengan baik dan kecenderungan siswa mempengaruhi keterlibatan siswa. Keterlibatan siswa tidak hanya dipengaruhi oleh minat dan tujuan, atau lingkungan pengajaran saja, tetapi interaksi merupakan hal yang penting. Keterlibatan tergantung pada apa yang guru dan siswa lakukan bersama, tidak bisa melakukannya sendiri (Kahu et al., 2017).

Mata pelajaran diselaraskan dengan minat siswa, bersama dengan guru yang memiliki informasi luas dan semangat memicu minat secara langsung dan mengarah pada kegemaran dan merasa memiliki yang akhirnya akan meningkatkan keterlibatan (Kahu et al., 2017) .

Keterlibatan siswa yang dipengaruhi minat terhadap hasil belajar. 
Jurnal PINUS: Jurnal Penelitian Inovasi Pembelajaran, 6 (2), 2021, Patmisari, Sri Setyawati, Achmad Muthali’in, Wibowo Heru Prasetiyo

Minat individu dan tujuan siswa bergabung ke dalam lingkugan pengajaran memicu minat situasional, yang pada gilirannya meningkatkan keterlibatan perilaku dan kognitif dan dengan demikian mengarah pada pembelajaran lebih baik dan meningkat. Minat situasional menuju minat individu terbukti, minat individu yang sudah ada sebelumnya digabungkan dengan konten dan lingkungnan kelas yang memicu minat situasional, terutama ketika siswa memaami pentingnya apa yang mereka pelajari.

Pembelajaran dianggap relevan bila ada keselarasan dalam antarmuka pendidikan antara tujuan siswa dan identitas professional yang muncul, dan tugas atau konten. Ketika siswa percaya apa yang mereka lakukan itu penting, untuk studi atau profesi mereka di masa depan, mereka akan lebih terlibat di dalam kelas. Dan sebaliknya jika tidak, mereka sering bosan, frustasi atau kurang termotivasi untuk melakukannya dengan baik sehingga kurang berusaha (Jang, 2016). Ciri-ciri sekolah yang menarik bagi siswa antara lain adanya "kolaborasi", “dukungan", “tempat aman", "rasa memiliki", "partisipasi dalam kehidupan komunitas", "komunikasi", "sikap adil", "perlakuan adil", "bebas mengungkapkan pikiran", dan "peristiwa menarik". Dan yang paling ditekankan adala ketika prestasi diperhatikan dan diakui oleh baik guru maupun teman kelas. Siswa akan merasa lebih terlibat di kelas ketika mereka dihormati, didukung, serta didorong untuk bekerja sama dengan yang lain (Devito, 2016).
Dari hasil penelitian Devito (2016) menunjukkan bahwa faktor-faktor yang memengaruhi keterlibatan siswa dalam konteks studi kasus dapat dikategorikan sebagai berikut.

1. Komunikasi, kolaborasi, keterlibatan aktif dalam kegiatan pembelajaran, dan memperkaya pengalaman pendidikan.

2. Interaksi antara siswa dan guru.

3. Tingkat tantangan akademik.

4. Lingkungan kelas yang mendukung.

5. Lingkungan keluarga mendukung.

Masing-masing faktor tersebut menghasilkan pengaruh tentang keinginan siswa untuk berpartisipasi dalam kegiatan pembelajaran dan persepsi siswa tentang pentingnya belajar.

\section{KESIMPULAN}

Hasil penelitian ini adalah analisis kemampuan berpartisipasi sebagai warga negara dalam pembelajaran PPKn pada siswa SMP Muhammadiyah 4 Surakarta, yaitu melalui pengamatan pada sikap dan perilaku peserta didik di sekolah. Keberhasilan guru dalam melihat indikator tolak ukur partisipasi belajar. Dari hasil penelitian menunjukkan bahwa terdapat keterlibatan siswa dalam pembelajaran PPKn di kelas, yaitu aktif mengerjakan soal yang diberikan guru, menjawab pertanyaan atau mengerjakan soal di depan kelas, memberi tanggapan terhadap jawaban siswa lain, membuat kesimpulan dari materi baik secara mandiri atau kelompok.

Akan tetapi masih terdapat kendala dalam analisis kemampuan berpartisipasi sebagai warga negara dalam pembelajaran PPKn pada siswa 
Jurnal PINUS: Jurnal Penelitian Inovasi Pembelajaran, 6 (2), 2021, Patmisari, Sri Setyawati, Achmad Muthali’in, Wibowo Heru Prasetiyo

SMP Muhammadiyah 4 Surakarta, yaitu kurang paham materi karena siswa tidak memperhatikan, kurangnya rasa percaya diri atas jawaban yang sudah dikerjakannya sendiri, siswa tertidur di kelas karena kurang fokus dalam belajar sehingga menyebabkan tidak paham materi dan tidak memberi tanggapan, kurangnya rasa percaya diri dalam menyampaikan pendapat dan siswa sering merasa jenuh ketika terlalu lama dalam pembelajaran.

Solusi yang diberikan untuk mengatasi kendala yang terjadi pada analisis kemampuan berpartisipasi sebagai warga negara dalam pembelajaran PPKn pada siswa SMP Muhammadiyah 4 Surakarta, yaitu dengan cara pengelolaan kelas yang baik oleh guru, memotivasi siswa untuk menjawab pertanyaan atau mengerjakan soal di depan kelas, menggunakan metode pembelajaran yang menarik siswa, guru memberikan ide awal dan guru memanfaatkan waktu dengan baik dalam kegiatan pembelajaran.

\section{DAFTAR RUJUKAN}

Azra, Azyumardi. 2005. Pendidikan Kewarganegaraan: Demokrasi, Hak Asasi Manusia, dan Masyarakat Madani. Jakarta: ICCE UIN Syarif Hidayatullah.

Baroutsis, A., McGregor, G., \& Mills, M. (2016). Pedagogic voice: student voice in teaching and engagement pedagogies. Pedagogy, Culture and Society, 24(1), 123-140. https://doi.org/10.1080/14681366 .2015 .1087044
Campbell, D. E., \& Niemi, R. G. (2016). Testing civics: State-level civic education requirements and political knowledge. American Political Science Review, 110(3), 495-511.

https://doi.org/10.1017/S0003055 416000368

Darmadi, H. (2013). Urgensi Pendidikan Pancasila dan Kewarganegaraan di Perguruan Tinggi. Bandung: Alfabeta.

Devito, M. (2016). Factors Influencing Student Engagement. Factors Influencing Student Engagement, 91.https://doi.org/http://digitalco mmons.sacredheart.edu/edl/11

Doppen, Frans H dkk. 2014. Young Adolescents" Knowledge and Notions of Citizenship. 13 (1): 16.

Fives, Allyn. 2015. Non-Coercive Promotion Of Values In Civic Education For Democracy. 39 (6): 577.

Groccia, J. E. (2018). What Is Student Engagement? New Directions for Teaching and Learning, 2018(154), 11-20. https://doi.org/10.1002/t1.20287

Hahn, C. L. (2016). Pedagogy in citizenship education research: A comparative perspective. Citizenship Teaching and Learning, 11(2), 121-138. https://doi.org/10.1386/ctl.11.2.1 21_1

Hooghe, M., Oser, J., \& Marien, S. (2016). A comparative analysis of 'good citizenship': A latent class analysis of adolescents' citizenship norms in 38 countries. 
Jurnal PINUS: Jurnal Penelitian Inovasi Pembelajaran, 6 (2), 2021, Patmisari, Sri Setyawati, Achmad Muthali'in, Wibowo Heru Prasetiyo

International Political Science Review, 37(1), 115-129. https://doi.org/10.1177/01925121 14541562

Hospel, V., \& Galand, B. (2016). Are both classroom autonomy support and structure equally important for students' engagement? A multilevel analysis. Learning and Instruction, 41, 1-10. https://doi.org/10.1016/j.learninst ruc.2015.09.001

Jang, H., Kim, E. J., \& Reeve, J. (2016). Why students become more engaged or more disengaged during the semester: A selfdetermination theory dual-process model. Learning and Instruction, 43, 27-38. https://doi.org/10.1016/j.learninst ruc.2016.01.002

Kahu, E., Nelson, K., \& Picton, C. (2017). Student interest as a key driver of engagement for first year students. Student Success, 8(2), 55.

https://doi.org/10.5204/ssj.v8i2.3 79

Kahu, E. R., \& Nelson, K. (2018). Student engagement in the educational interface: understanding the mechanisms of student success. Higher Education Research and Development, 37(1), 58-71. https://doi.org/10.1080/07294360 .2017 .1344197

Kementerian Pendidikan dan Kebudayaan Republik Indonesia. 2014. Pendidikan Pancasila dan Kewarganegaraan SMP/ MTs Kelas VIII. Jakarta: Kementerian Pendidikan dan Kebudayaan Republik Indonesia.
Knowles, R. T., Torney-Purta, J., \& Barber, C. (2018). Enhancing citizenship learning with international comparative research: Analyses of IEA civic education datasets. Citizenship Teaching and Learning, 13(1), 730.

https://doi.org/10.1386/ctl.13.1.7 -1

Lee, E., \& Hannafin, M. J. (2016). A design framework for enhancing engagement in student-centered learning: own it, learn it, and share it. Educational Technology Research and Development, 64(4), 707-734. https://doi.org/10.1007/s11423015-9422-5

Masika, R., \& Jones, J. (2016). Building student belonging and engagement: insights into higher education students' experiences of participating and learning together. Teaching in Higher Education, 21(2), 138-150. https://doi.org/10.1080/13562517 .2015 .1122585

Mirra, N., \& Garcia, A. (2017). Civic Participation Reimagined: Youth Interrogation and Innovation in the Multimodal Public Sphere. Review of Research in Education, 41(1), 136-158. https://doi.org/10.3102/0091732 X17690121

Mutch, Carol. 2011. Citizenship Education in New Zealand: we know ,what works" but to what extent is it working?. 10 (2-3): 18.

Rachmawati, Winda Ayu. 2016. "Penggunaan Media Film 
Jurnal PINUS: Jurnal Penelitian Inovasi Pembelajaran, 6 (2), 2021, Patmisari, Sri Setyawati, Achmad Muthali'in, Wibowo Heru Prasetiyo

Dokumenter untuk Meningkatkan Pemahaman Peserta Didik dalam Pembelajaran Proklamasi dan Konstitusi”. Skripsi. Bandung: Jurusan Pendidikan Kewarganegaraan Universitas Pendidikan Indonesia.

Reichert, F., \& Print, M. (2018). Civic participation of high school students: the effect of civic learning in school. Educational Review, 70(3), 318-341. https://doi.org/10.1080/00131911 .2017 .1316239

Rossi, G., Lenzi, M., Sharkey, J. D., Vieno, A., \& Santinello, M. (2016). Factors Associated with Civic Engagement in Adolescence: The Effects of Neighborhood, School, Family, and Peer Contexts. Journal of Community Psychology. https://doi.org/10.1002/jcop.2182 6

Shernoff, D. J., Kelly, S., Tonks, S. M., Anderson, B., Cavanagh, R. F., Sinha, S., \& Abdi, B. (2016). Student engagement as a function of environmental complexity in high school classrooms. Learning and Instruction, 43, 52-60. https://doi.org/10.1016/j.learninst ruc.2015.12.003

Undang-Undang No. 20 Tahun 2003 Tentang: Sistem Pendidikan Nasional.

Winataputra, U. S. (2012). Pendidikan kewarganegaraan dalam perspektif pendidikan untuk mencerdaskan kehidupan bangsa: gagasan, instrumentasi, dan praksis. Bandung: Widya Aksara Press. 